\title{
The Antibacterian Activity of Lactococcus lactis sbsp cremoris against Salmonella $S p$
}

\author{
Menad N ${ }^{1 *}$, Cheriguene $\mathrm{A}^{1}$, Belarbi $\mathrm{F}^{2}$, Hammouni $\mathrm{R}^{3}$ and Moghtet $\mathrm{S}^{4}$ \\ ${ }^{1}$ Laboratory of Microbiology and Plant Biology, Faculty of Natural Sciences and Life, University of Mostaganem, Algeria \\ ${ }^{2}$ Laboratory of Food and Industrial Microbiology, Department of Biology, Faculty of Science, University of Oran, Algeria \\ ${ }^{3}$ Veterinary National School, B.P. 161 Hacène Badi - EL Harrach - Algiers, Algeria \\ ${ }^{4}$ Laboratory of Microbiology, Faculty of Natural Sciences, University of Bechar, Algeria
}

\begin{abstract}
This study focused on the benefices effects of micro-organisms called probiotics that is Lactococcus lactis sbsp cremoris CNRZ 107, and propose different therapeutic possibilities of our situation against a pathogen Salmonella sp.

We conducted two tests in vitro and in vivo; where it was noted that treatment in the presence of this lactic strain is effective because it causes a remarkable decrease of the pathogen agent.

In the end, the effectiveness of this lactic strain was confirmed by testing for resistance to gastrointestinal conditions ( $\mathrm{pH}$, bile salts and digestive enzymes).
\end{abstract}

Keywords: Salmonella Sp; Lactococcus lactis sbsp cremoris; Probiotics; Albino mice; Gastrointestinal conditions

\section{Introduction}

The man like animals, live continuously in combination with its resident population of the gastrointestinal tract complex microorganisms. One of the main benefits from their alliance is the protection and improvement of resistance to infectious diseases of the host organism [1].

However, the composition of the digest if flora can be altered by various dietary and environmental factors that make the host organism susceptible to disease or digestive disorders caused by fungi and viruses as well as bacteria such as Salmonella sp.

In this work we tried to protect or prevent diseases caused by pathogenic strain that causes serious illness in humans and can lead to death as well, which is Salmonella $s p$ using a probiotic lactic type strain Lactococcus lactis sbsp cremoris CNRZ 107.

We performed an in vitro test and have confirmed or validated by an in vivo test on animals and we did tests is to investigate the ability of this strain lactic used to withstand extreme conditions of the digestive.

\section{Materials and Methods}

\section{Materials}

The strains used in this study are: Lactococcus lactis sbsp cremoris CNRZ 107, producing a reference strain that was kindly provided to us by Professor Françoise Berthier of INRA-Station de Recherches en Technologie et Analyses Laitières, Poligny, France. This strain is stored in glycerol at $-20^{\circ} \mathrm{C}$. Prior to their use in testing, they were activated by transfer on M17 broth [2].

And Salmonella sp, an indicating pathogenic strain that has been isolated on SS medium provided by the Veterinary Research Laboratory, University of Tiaret - Algeria. This strain was maintained on nutrient agar slant at $4^{\circ} \mathrm{C}$. Prior to their use in testing, it has been activated by transfer nutrient broth.

Conventional mouse strain NMRI SWISS were used in this protocol, aged 6 weeks and provided by a specialized laboratory for culturing mouse: the pet service of the Pasteur Institute in Algiers Algeria.

\section{Methods}

Identification of strains: The identification of our strains was based on the determination of morphological and biochemical characteristics, we performed a Gram stain and a urease test and a macroscopic examination, is to study the shape, appearance, contour, the surface, the colour of the colonies on M17 agar and SS agar.

Study the survival of lactic strain in the extreme conditions of the digestive tract

Effect of $\mathbf{p H}$ and bile salts: The method used is that of Dilmi Bouras [3], which is to prepare two fractions of $5 \mathrm{ml}$ of M17 broth which the first is devoid of bile while the second is added $0.3 \%$ salts, each fraction will undergo $\mathrm{pH}$ adjustment (by addition of $\mathrm{HCl}$ ) to 1.0. In these fractions are added 3\% inoculums of lactic pure strain Lactococcus lactis sbsp cremoris CNRZ 107. These fractions were then incubated at $37^{\circ} \mathrm{C}$ followed by counts on M17 medium during the following time intervals: $0 \mathrm{~h}, 2 \mathrm{~h}, 4 \mathrm{~h}$ and $24 \mathrm{~h}$.

Effect of digestive enzymes (pepsin): In a test tube, put $5 \mathrm{ml}$ of lactic culture pure (18 h) Lactococcus lactis sbsp cremoris CNRZ 107, and then add $10^{-3} \mathrm{~g} / \mathrm{ml}$ pepsin. This fraction was then incubated at $37^{\circ} \mathrm{C}$ where the growth is controlled by close counts on M17 medium during the following time intervals: $0 \mathrm{~h}, 2 \mathrm{~h}, 4 \mathrm{~h}$ and $24 \mathrm{~h} \mathrm{[3].}$

*Corresponding author: Menad Najett, Researcher, Research Field: Microbiology, University of Mostaganem, Algeria, Tel: (213)45265455; E-mail: na_11011986@yahoo.fr

Received October 05, 2013; Accepted January 14, 2014; Published January 24 2014

Citation: Menad N, Cheriguene A, Belarbi F, Hammouni R, Moghtet S (2014) The Antibacterian Activity of Lactococcus lactis sbsp cremoris against Salmonella Sp. J Med Microb Diagn 3: 129. doi:10.4172/2161-0703.1000129

Copyright: ( 2014 Menad N, et al. This is an open-access article distributed under the terms of the Creative Commons Attribution License, which permits unrestricted use, distribution, and reproduction in any medium, provided the original author and source are credited. 
In vitro adhesion to epithelial tissue: The method described by Lin and Chien [4], which has three stages, was involved:

\section{- Preparation of epithelial cells:}

A segment of the colon of a broiler was opened and washed with sterile phosphate buffered saline (PBS pH 7.2) and held in PBS at $4^{\circ} \mathrm{C}$ for $30 \mathrm{~min}$ for washing. Thereafter, the tissue was taken, washed 10 times with sterile PBS and allows standing at $4^{\circ} \mathrm{C}$ for $3 \mathrm{~h}$. The cells were harvested by scraping the surface lining the colon through a sterile blade. Decimal dilutions were made up to $10^{-4}$.

\section{- Preparation of close up:}

A young bacterial culture was centrifuged at 6000 turn/10min and the pellet was recovered in $2 \mathrm{ml}$ PBS.

\section{- Carrying out the test:}

$1 \mathrm{ml}$ of culture was mixed with $1 \mathrm{ml}$ of the $10^{-4}$ dilution of the cell suspension colon already prepared. After incubation at $37^{\circ} \mathrm{C}$ for 40 minutes, a smear preparation and staining with $0.5 \%$ crystal violet for 5 min was performed to observe adherence to the optical microscope. The test is considered positive if the number of adhered bacteria is greater than 15 .

Test hydrophobicity: The hydrophobicity is determined according to the method described by Iyer et al, (2010): a young culture of 18 $\mathrm{h}$ was prepared in M17 broth. The bacterial pellet was recovered by centrifugation cold 12000 turn/5min followed by two successive washes and then resuspended in $1.2 \mathrm{ml}$ of magnesium phosphate buffer ( $\mathrm{pH}$ 6.5) [5].

The initial optical density of the suspension was adjusted to approximately 1.0 at $450 \mathrm{~nm}\left(\mathrm{OD}_{\text {initial }}\right)$. Then $0.6 \mathrm{ml}$ of xylene was added slowly to $3 \mathrm{ml}$ of the bacterial suspension and incubated at $37^{\circ} \mathrm{C}$ for 10 min. This mixture was stirred using a vortex for $2 \mathrm{~min}$.

After $15 \mathrm{~min}$, the aqueous phase is recovered using a pasteur pipette and we proceed to the final measurement of Optical Density $\left(O D_{\text {final }}\right)$.

The difference in optical density is considered a measure of the hydrophobicity of the cell surface $(\mathrm{H} \%)$ calculated by the following equation: \% hydrophobicity=Initial OD-Final OD/OD initial $\times 100$.

\section{Antibiogramm}

Antibiotic susceptibility was tested by the diffusion method (method of disks) on Muller-Hinton medium, using four antibiotics discs, namely: Tetracycline, Penicillin, Chloramphenical and Erythromycin. After incubation at $37^{\circ} \mathrm{C}$ for $24 \mathrm{~h}$, the diameters of the zones of inhibition were measured [6].

\section{Test in vitro}

The revelation of the spectrum of antimicrobial activity was performed according to the method of well diffusion which has been advocated by Tagg and Mc [7].

In a petridish containing solid GN is flooded by a youth culture (18 h) of the indicator strain $\left(\mathrm{OD}_{660}=0.08\right.$ and 0.1$)$ [8], wells are made with a cookie cutter. These wells will $10^{-1} \mathrm{ml}$ lactic culture to be tested.

The petri dishes are prepared and pre incubated for 2-4 hours at $4^{\circ} \mathrm{C}$, then followed by incubation for 24 hours at $37^{\circ} \mathrm{C}$ [9]. The presence of a clear zone around the wells, indicating the absence of growth of the indicator strain [10-12].

\section{Test in vivo}

The first part consists the study of intestinal flora and an axenic control of mice tested (count on day 0 ). The second part concerns the infected mice subjected to treatment with lactic pure strain to follow their evolution in droppings and their installation level bodies and their contents (stomach, intestine) and monitor their effect to the pathogen (count on day 4, 7, 10). For this test we have provided for:

- Group 1 (control group), of two mice, the mice were not treated with the probiotic and are not infected by the pathogenic strain and receive normal cattle food;

- Group 2 of 4 mice, the mice are infected by $0.2 \mathrm{ml}$ Salmonella $s p$, for three days two times a day;

- Group 3 of 4 mice, the mice received $0.2 \mathrm{ml}$ of Lactococcus lactis sbsp cremoris CNRZ 107 for three days two times a day;

- Group 4 of 5 mice, conventional mice are subjected to a phase of implementation by $0.2 \mathrm{ml}$ of Lactococcus lactis sbsp cremoris CNRZ 107 for three days two times a day, then a phase of infection by $0.2 \mathrm{ml}$ Salmonella sp after the last dose (day 4) for the next three days 2 times a day [13].

The dose of each strain (indicative and producer) was measured by the spectrophotometer $\mathrm{OD}_{660}=1.2$, indicates a rate $>10^{8} \mathrm{CFU}$, because the minimum level of probiotic bacteria necessary to establish a beneficial effect was estimated at between $10^{6}$ and $10^{8}$ UFC [14].

The probiotic strain Lactococcus lactis sbsp cremoris CNRZ 107 was selected on M17 agar supplemented with a chloramphenical antibiotic. This selective medium was subsequently used for the enumeration before (day 0 ) and after gavage (day 4 , day 7 and day 10) to assess the levels of normal flora capable of growth on selective media [13].

\section{Results and Discussion}

\section{Results}

The first step of this study is to purify and identify the bacterial strains (indicator and producers) used for this work. The pre identification of Lactococcus lactis sbsp cremoris CNRZ 107 shows that the colonies obtained on M17 medium appeared small, circular or lenticular shape, regular edges and whitish, the cells are presented in Gram positive hull shape.

Salmonella $s p$, our strain was Gram-negative, indole negative, colonies of 2 to $4 \mathrm{~mm}$ in diameter and colourless.

The second step is to investigate the ability of our strain lactic used Lactococcus lactis sbsp cremoris CNRZ 107 to resist digestive conditions.

Strain lactic gave no growth on M17 medium supplemented with $0.3 \%$ bile salts at $\mathrm{pH}=1$ to time 2 hours, 4 hours and 24 hours in comparison with the 0 hours time. The study of the prolonged exposure of the strain lactic acids with similar conditions to those of the stomach shows the existence of a continuing viability of individual strain decreasing with time (from 0 hours to 24 hours) (Figure 1).

According to the adhesion test, it appears that the strain showed adherence to epithelial cells of the colon Broiler (Figure 2).

The percentages of adhesion on xylene of our strain pure indicate hydrophobicity of their surface. The result of this test is illustrated by the value of $45 \%$. These results show that the strain put to the test has good hydrophobicity, this reflects a good selectivity of the membrane surfaces. 
According to the susceptibility test, we found that our strain lactic shown resistance to Penicillin (P) and Chloramphenical (C) and sensitivity to: Tetracycline (TET) $(36 \mathrm{~mm})$ and Erythromycin (E) $(40$ $\mathrm{mm}$ ) (Figure 3).

The in vitro test has a bactericidal effect against Salmonella sp which prove the presence of an inhibition well zone of $10 \mathrm{~mm}$ (Figure 4).

The enumeration of our probiotic strain Lactococcus lactis sbsp cremoris CNRZ 107 on day 0 was carried out on M17 and M17 medium + Chloramphenical for mice of each group in the feces and organs (stomach, intestine).

After $24 \mathrm{~h}$ of incubation was found the presence of a large number of settlements in the droppings and both stomach and intestinal organs producing strain on M17 medium for mice in each group, compared with the M17 medium + Chloramphenical where there was $0 \mathrm{CFU} / \mathrm{g}$ sample for the four groups.

M17 medium supplemented with the antibiotic is an effective

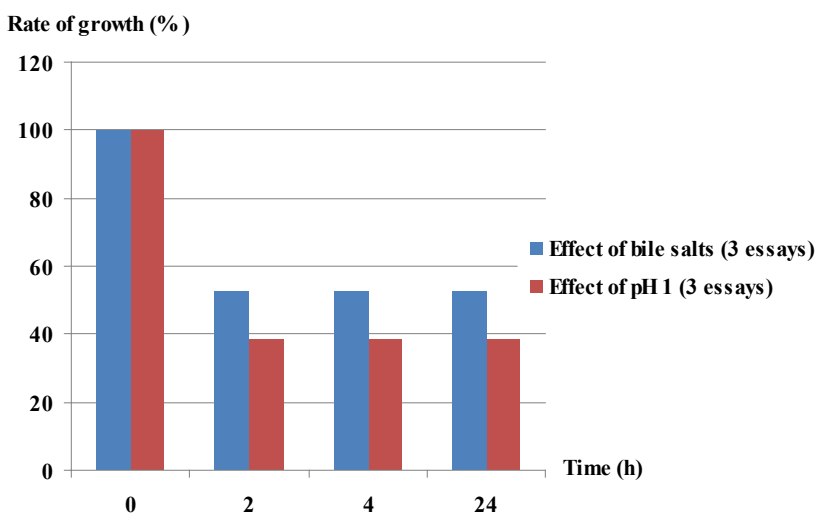

Figure 1: Influence of bile salts and $\mathrm{pH}$ on the growth of Lactococcus lactis sbsp cremoris CNRZ 107.

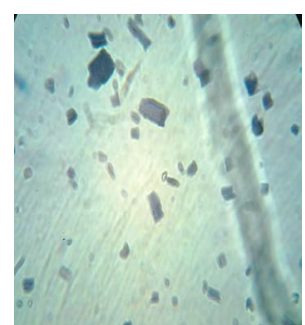

Figure 2: Adhesion test of Lactococcus lactis sbsp cremoris CNRZ 107 on colon epithelial tissue.

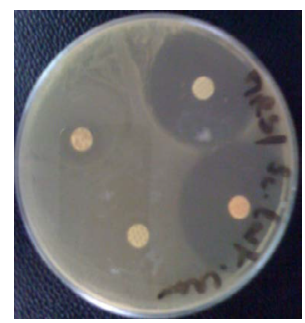

Figure 3: Antibiogramm of Lactococcus lactis sbsp cremoris CNRZ 107.

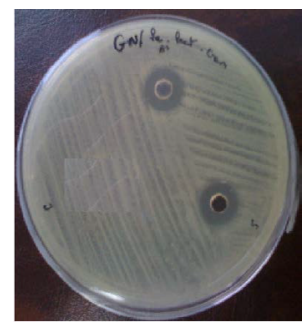

Figure 4: Bactericidal effect of Lactococcus lactis sbsp cremoris CNRZ 107 on Salmonella $s p$.

and selective medium for a count of lactic strain that was used in the following steps (counts at day 4,7 and 10).

After counting on M17 medium + chloramphenical, Lactococcus lactis sbsp cremoris CNRZ 107 for group 3 and 4, there was a change in the number of CFU/g sample (feces, intestine, stomach) in days $0,4,7$ compared with group 1 (control) (Figure 5).

The absence of Salmonella sp. in feces and in the organs (stomach, intestine) was the criterion of confirmation axenic mice used in this experiment. The bacteriological analysis of feces and organs (stomach, intestine) with their content for all groups of mice before testing reveals no presence of Salmonella $s p$ on day 0 . These results were compared with the number obtained in group 2, where there has been an increase in the number of CFU/g sample in days $0,4,7$ and 10 . And the number of the pathogen was reduced after gavage strain lactic (Figure 6).

\section{Discussion}

The results of the identification tests of our strains (Salmonella $s p$, Lactococcus lactis sbsp cremoris CNRZ 107) were the same in comparison with those obtained by Popoff and hall (1997) Bergey's Manual Of Systematic Bacteriology, Second Edition, Volume Two, The Proteobacteria [15] and Schleifer et al. (1985) in Bergey's Manual Of Systematic Bacteriology, Second Edition, Volume Three, The Firmicutes [16].

Resistance to digestive conditions is a key point in our study, so the study of some growth parameters such as bile, which is a detergent, resistance to bile salts appears to be associated with the stability of the cell membrane.

The effect of $\mathrm{pH}$ on microbial growth is on three levels: the enzymatic activity of the membrane, the permeation and bioavailability of certain nutrients which depends on the ionic balance.

The hydrophobicity test evaluates the hydrophobicity of the cell surface of our probiotic strain pure against xylene may reflect the colonization potential of close to intestinal mucus. The distribution of cells between the aqueous phase and the resulting xylene hydrophobic interaction between micro-organisms and hydrocarbons. The hydrophobicity of the cell wall is a physico-chemical property that facilitates the first contact between the micro-organisms and the host cells. Thus, it appears to be a factor helping to grip, but it does not contribute to good adhesion $[17,18]$.

The resistance to Chloramphenicol antibiotic is used to prepare a selective enumeration medium of Lactococcus sp. This antibiotic resistance may be a problem if it can be transmitted pathogens in which therapeutic resistance could have adverse consequences. Similarly, the European Food Safety Authority suggests that probiotics may not have acquired resistance to antibiotics [19]. 

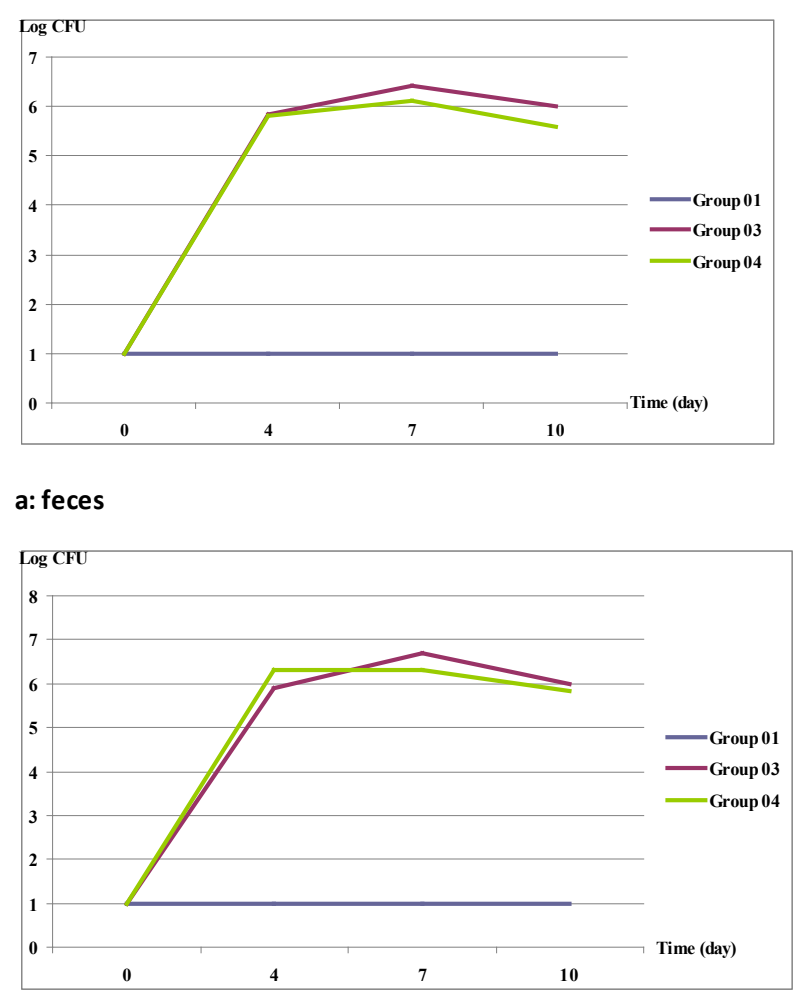

\section{b: intestine}

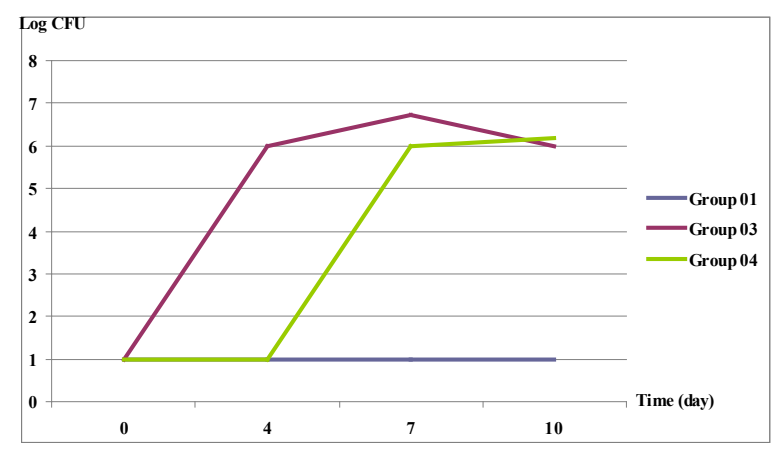

c: stomach

Figure 5: Evolution of Lactococcus lactis sbsp cremoris CNRZ 107 on M17 medium + chloramphenical over time.

The results in vitro test indicate that our lactic bacterium is able to synthesize inhibitors with antibacterial activity.

In addition, lactic bacteria are known to produce a variety of antimicrobial compounds: organic acids, bacteriocins, diacetyl, and hydrogen peroxide [20,21]. Charlier and hall showed that Lactococcus $s p$ has a broad-spectrum inhibition against Salmonella $s p$ which is induced by the effect of lactic acid and bacteriocins [22].

The results in vivo test, the Lactococcus administered are able to quantitatively alter the intestinal microflora in young animals during withdrawal and this is probably due to the survivability of Lactococcus lactis sbsp cremoris CNRZ 107 under acidic conditions is generally better.

The bacterial population increases, however in more remote portions of the small intestine is the most important place for digestion and absorption and also for the activity of probiotics electrolytic pancreatic secretion is rich in bicarbonates, it can buffer acidity from the stomach and thus optimum $\mathrm{pH}$, it is probably for this reason that our probiotic strains are present [23].

The study of the survival of lactic bacteria in the gastrointestinal tract is important for a better understanding of the fate of ingested with food lactic acid bacteria and a better understanding of the action of probiotics, we did a head count of our strain probiotic throughout the duration of the experiment and on selective medium (M17 + chloramphenical) to confirm that they are living in the digestive tube and also they must implement in vivo in the digestive tract or they have only over steer during transit.

Indeed, the results indicate a decrease in the number of pathogenic bacteria in the feces and in the organs with their contents. Repressing the growth of this pathogen can be done in several ways, depending

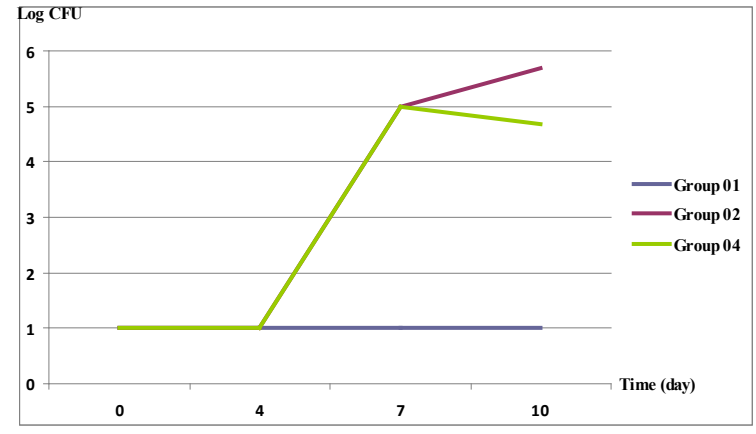

a: feces

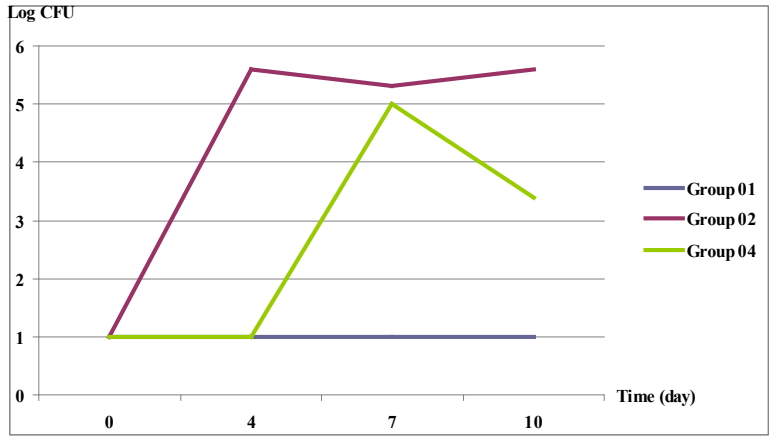

b: intestine

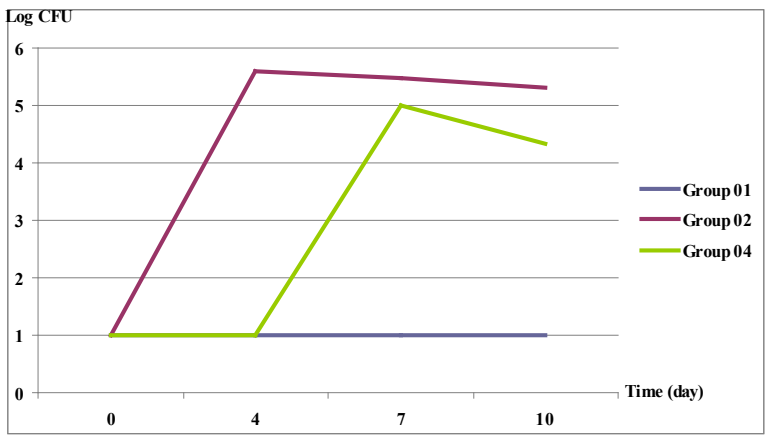

c: stomach

Figure 6: Evolution of Salmonella sp over time after counting on SS medium. 
on the number and type of probiotics through mechanisms such as specific microbial activities (production of certain enzymes or growth factors), microbial interactions (production antimicrobial components such as hydrogen peroxide, weak organic acids [24] and antibacterial peptides), interactions with the intestinal epithelium (competition for receptors on the intestinal epithelium) and interactions with the immune system [25], by direct secretion of bacteriocins [26], protease production [27] against bacterial toxins.

\section{Conclusion}

The first step of this study is to obtain a strain of lactic bacterium is a contribution from us in the acquisition of a bank of lactic strains that will subsequently the subject of our study.

The second stage study for interest highlighting various strains of lactic bacteria which possess interesting properties of resistance, such as resistance to acidic $\mathrm{pH}$ and bile salts, adhesion to the epithelium of the colon as well as the study of the effect of these bacteria against the pathogen Salmonella sp.

According to the in vitro test, our lactic strain has a very apparent bactericidal effect manifested by the appearance of clear halos goshawks wells.

According to the test in vitro, we concluded that the probiotic Lactococcus lactis sbsp cremoris CNRZ 107 used in the treatment causes a significant reduction in pathogen, improve health and ensure the maintenance of the ecological balance of the microflora tract, these beneficial interests were clearly observed in the present study.

\section{References}

1. Sullivan A, Nord CE (2005) Probiotics and gastrointestinal diseases. J Intern Med 257: 78-92.

2. Terzaghi BE, Sandine WE (1975) Improved medium for lactic streptococci and their bacteriophages. Appl Microbiol 29: 807-813.

3. Dilmi Bouras A (2002) Survie de Streptococcus thermophilus et Lactobacillus bulgaricus et leur action sur la métabolisme du cholestérol. Thèse de doctorat d'état, INA, El Harrach, Alger.

4. Lin TY, Chien MFC (2007) Exopolysaccharides production as affected by lactic acid bacteria and fermentation time. Food Chem 100: 1419-1423.

5. Iyer R, Tomar SK, UmaMaheswari T, Singh R (2010) Streptococcus thermophilus strains: multifunctional lactic acid bacteria. Int Dairy J 20: 133141.

6. Leroy S, Lebert I, Chacornac JP, Chevalier I, Talon R (2007) Identification et caractérisation de la flore d'intérêt technologique : bactéries lactiques et staphylocoques à coagulase négative. Sci Tec V Prod Carnés 25:172.

7. Tagg JR, McGiven AR (1971) Assay system for bacteriocins. Appl Microbio 21: 943.

8. Hadef S (2012) Evaluation des aptitudes technologiques et probiotiques des bactéries lactiques locales. Université de Ouargla.

9. Beliard E (1990) Sélection des souches de bactéries lactiques inhibitrices de contaminants des viandes et études des mécanismes d'inhibitions. Application à la conservation des produits carnés. Thèse de Doctorat en sciences alimentaires.

10. Kaban, Kaya MG (2006) Effect of starter culture on growth of Staphylococcus aureus in sucuk. Food control 17: 797-801.

11. Barefoot SF, Klaenhammer TR (1983) Detection and activity of lactacin B, a bacteriocin produced by Lactobacillus acidophilus. Appl Environ Microbiol 45 1808-1815.

12. Pulsani, Rao DR, Sunki GR (1979) Antimicrobial Activity of lactic cultures partial purification and characterization of antimicrobial compounds produced by Streptococcus thermophilus. J Food Science 44: 575-578.

13. Hee Ji Lee, David A, Orlovich, John R, Tagg, et al. (2009) Detection and Speci?c Enumeration of Multi-Strain Probiotics in the Lumen Contents and Mucus Layers of the Rat Intestine after Oral Administration. Probiotics \& Antimicro Prot 1: 113-120.

14. Conway PL, Gorbach SL, Goldin BR (1987) Survival of lactic acid bacteria in the human stomach and adhesion to intestinal cells. J Dairy Sci 70: 1-12.

15. Popoff MY, Bockemühl J, Brenner FW (1998) Supplement 1997 (no. 41) to the Kauffmann-White scheme. Res Microbiol 149: 601-604.

16. Schleifer KH, Kraus J, Dvorak C, Kilpper-Bälz R, Collins MD, et al. (1985) Transfer of Streptococcus lactis and related streptococci to the genus Lactococcus gen. Nov Syst Appl Microbiol 6: 183-195.

17. Roos S, Jonsson H (2002) A high-molecular-mass cell-surface protein from Lactobacillus reuteri 1063 adheres to mucus components. Microbiology 148: 433-442.

18. Guglielmotti DM, Marco MB, Golowezye M, Reinheimer JA, Quiberoni ADL (2007) Probiotic potential of Lactobacillus delbrueckii strains and their phage resistant mutants. Int Dairy J 17: 916-925.

19. Zago M, Fornasari ME, Carminati D, Burns $P$, Suàrez V, et al. (2011) Characterization and probiotic potential of Lactobacillus plantarum strains isolated from cheeses. Food Microbiol 28: 1033-1040.

20. Titiek FD, Endang SR, Djoko W, Slamet S (1996) Antimicrobial substance produced by Lactobacillus sp. TGR-2 isoleted from Growol. Indonesian. Food Nutr. Prog 3: 29-34.

21. Aslam S, Qazi JI (2010) Isolation of acidophilic lactic acid bacteria antagonistic to microbial contaminants. Pakistan. J Zool 42: 567-573.

22. Charlier C, Cretenet M, Even S, Le Loir Y (2009) Interactions between Staphylococcus aureus and lactic acid bacteria: an old story with new perspectives. Int J Food Microbiol 131: 30-39.

23. Esther IA (2009) Les protéines bactériennes en tant que biomarqueurs de l'activité probiotique. Université de Strasbourg.

24. Liévin V, Peiffer I, Hudault S, Rochat F, Brassart D, et al. (2000) Bifidobacterium strains from resident infant human gastrointestinal microflora exert antimicrobial activity. Gut 47: 646-652.

25. De Vuyst L, Avonts L, Makras E (2004) Probiotics, prebiotics and gut health Functional Foods: Ageing and Degenerative Disease. Wood head Publishing Ltd., Cambridge, United Kingdom.

26. Cotter PD, Hill C, Ross RP (2005) Bacteriocins: developing innate immunity for food. Nat Rev Microbiol 3: 777-788.

27. Castagliuolo I, Riegler MF, Valenick L, LaMont JT, Pothoulakis C (1999) Saccharomyces boulardii protease inhibits the effects of Clostridium difficile toxins A and B in human colonic mucosa. Infect Immun 67: 302-307. 